Research article

\title{
MORPHOLOGICAL, BIOCHEMICAL AND HEMATOLOGICAL CHARACTERIZATION OF ENDANGERED BALKAN DONKEY BREED
}

\author{
STANIŠIĆ Ljubodrag ${ }^{1 *}$, DIMITRIJEVIĆ Vladimir ${ }^{2}$, SIMEUNOVIĆ Predrag ${ }^{1}$, \\ LAKIĆ $\mathrm{Nada}^{3}$, RADOVIĆ Ivica ${ }^{4}$, IVANKOVIĆ Ante ${ }^{5}$, STEVANOVIĆ Jevrosima ${ }^{1}$, \\ STANIMIROVIĆ Zoran ${ }^{1}$
}

\begin{abstract}
${ }^{1}$ Department of Biology, Faculty of Veterinary Medicine, University of Belgrade, Bul. Oslobodjenja 18, 11000 Belgrade, Serbia; ${ }^{2}$ Department of Animal Breeding and Genetics, University of Belgrade, Bul. Oslobodjenja 18, 11000 Belgrade, Serbia; ${ }^{3}$ Department of Statistics, Faculty of Agriculture, University of Belgrade, Nemanjina 6, 11080 Belgrade, Serbia; ${ }^{4}$ Civil Protection and Environment Protection Studies Department, Faculty of Security Studies, University of Belgrade, Gospodara Vucica 50, 11040 Belgrade, Serbia; ${ }^{5}$ Department of Animal Science and Technology, Faculty of Agriculture, University of Zagreb, Svetosimunska cesta 25, 10000 Zagreb, Croatia
\end{abstract}

The aim of the study was to establish morphometric, biochemical and hematological values for the endangered Balkan donkey breed (Serbia) and to explore the possible age dependence of the parameters tested. Inter-breed similarity of morphometric parameters was assessed by comparing the data obtained for the Balkan donkey with morphometric measurements of several previously characterized domestic donkey breeds. The study population included 74 donkeys, divided in two age groups (group A $\leq 3$ years; group B $>3$ years). In total, 18 morphometric, 13 hematological and 14 biochemical parameters were assessed. Significant morphometric differences $(\mathrm{p}<0.05)$ in body length, head length, chest circumference and body weight were found between the two age groups. Significant differences in morphological parameters were revealed among the Balkan donkey and other donkey breeds (Catalonian, Croatian and Albanian), but results of cluster analysis demonstrated the smallest distance between the Balkan donkey and Albanian donkeys. The results of morphometric analyses showed consistency of the obtained values within the breed, and diversity as compared to other donkey breeds, and, thus, could be taken as referent for the Balkan donkey. Hematological and biochemical profiles obtained for the Balkan donkey were consistent with previous reports and within the recommended reference ranges. White blood cell, mid cell and granulocyte counts, showed significantly higher $(\mathrm{p}<0.05)$ values in donkeys under 3 years of age, while the only biochemical parameter affected by age was alkaline phosphatase. The information gained through characterization of the Balkan donkey breed provides a basis for conservation and development of the breed standard.

Key words: Breed characterization, blood parameters, Balkan donkey, morphological measures

Corresponding author: e-mail: motoljuba@gmail.com 


\section{INIRODUCTION}

Protection of genetic resources is one of the crucial issues aimed at biodiversity conservation as autochthonous breeds are vanishing at a disturbing rate. Substantial decrease in population size might create high levels of inbreeding in such breeds. This may result in inbreeding depression with the risk of breed extinction. Investigation of Beja-Pereira et al. [1] indicate that the majority of European donkey breeds originate from two African wild breeds: the Nubian wild donkey (E quus asinus africanus) and the Somalian wild donkey (E quus asinus somaliensis). It is worth mentioning that both of these breeds are nowadays critically endangered. According to the report of Kugler et al. [2] there are approximately 185 donkey breeds worldwide. The number of individuals in certain breeds is alarmingly low and demands an intervention to guarantee their survival $[3,4]$. Only several donkey breeds have been described in accordance with the recommendation of Food and Agriculture Organization [5,6]. Such are for example the studies on Spanish [7-12] and Croatian donkey breeds [13,14].

The Balkan donkey is an endangered autochthonous breed widespread across the Serbian territory $[2,15]$. Over the last decades, the population of the Balkan donkey has been constantly declining due to intensive agrarian production and the socioeconomic changes in the rural areas. It is estimated that the current number of sexually mature Balkan donkeys in Serbia is as low as 250-300 and they are under some form of surveillance and protection [16].

The initial research in the process of donkey breed preservation relies on the phenotype study including the geographical distribution and morphometric characterization, along with the age and sex differences $[5,7,13,17]$. In addition to the morphological description, determination of hematological and biochemical profiles of donkey breeds take important place in the process of breed characterization. The hematological and biochemical reference values for Balkan donkey have not been defined and they were described only for a small number of donkey breeds [8,9,18-23]. In addition to their importance in the breed characterization, hematological and biochemical parameters may also be clinically relevant. They can provide valuable information concerning the metabolic status of an individual or a herd, severity and systemic effects of a disease, response to the treatment etc. [8,9,20,23-25].

Scientifically based data on donkey population in Serbia are lacking. The only available data are basic body measures [16] and major hematological parameters [26]. Both these surveys, however, included a small number of Balkan donkeys located in Stara planina Mt. region. The aim of our study was to establish biochemical, hematological and morphometric values for the endangered Balkan donkey breed by using a representative sample acquired from two age categories. In order to assess inter-breed similarity within a context of morphometric parameters, the data obtained for the Balkan donkey were compared with morphometric parameters of several previously characterized domestic donkey breeds. 


\section{MATERIALAND METHODS}

\section{The Balkan donkey population}

The majority of donkey population in Serbia is situated in following locations: the Special Nature Reserve “Zasavica” (SNR “Zasavica”, 44057' 32,2" N 19031'32,7" E),

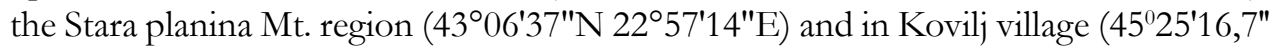
N $\left.19^{\circ} 83^{\prime} 69,4^{\prime \prime} \mathrm{E}\right)$ near Novi Sad. Besides, small number of adult donkeys and foals is distributed over the country in individual households. In total, 74 animals have been included in this survey: 39 donkeys from SNR „Zasavica“, 16 donkeys from Stara planina Mt. and 19 donkeys located in Kovilj village. The study population included 6 males and 68 females. In accordance with the previous investigations [8,9], the study population was consisted of two age groups. Group A included 22 young donkeys ( $\leq$ 3 years of age), while group B included 52 adult donkeys older than 3 years. The oldest animals in group B were 10 years old.

\section{Morphometric measurements}

In total, 18 body measures were selected for morphometric characterization of the Balkan donkey. For six body variables (chest circumference, carpal circumference, tarsal circumference, tibia circumference, ear length and head length) a measuring tape was used. The additional 11 parameters (wither height, back height, hip height, chest depth, carpal height, tarsal height, body length, head width, chest width, croup length and croup width) were measured by the Lydtin stick. The body weight (BW) for each animal was calculated according to the formula:

$$
\mathrm{BW}(\mathrm{kg})=\left(\mathrm{CC}^{2} \mathrm{x} \mathrm{BL}\right) / 11877
$$

where CC and BL represent chest circumference and body length, respectively [27]. Microchip number, followed by age, coat color, specific distinctive signs and possible external defects were recorded for each animal.

The five body measures selected for inter-breed analysis among Balkan donkey and Catalonian donkey [7], Croatian donkeys [13] and Albanian donkeys [17] were: wither height, chest depth, body length, chest width and chest circumference.

\section{Blood sampling}

Blood was sampled from 74 clinically healthy donkeys by venepunction of the jugular vein, over the period from May to August 2013. The stress was minimized by handling the animals with care before the collection of samples. The blood was collected in EDTA tubes for hematological studies, and into vacutainer tubes without anticoagulant for serum extraction. Immediately after sampling, the tubes were chilled on ice. Hematological profile and serum separation were performed within $12 \mathrm{~h}$ following the blood sampling. Plasma and serum were harvested by centrifugation at $2.800 \mathrm{x} g$ for 5 minutes. The sera samples were stored at $-20^{\circ} \mathrm{C}$ prior to biochemical analysis. Complete 
blood counts with related parameters were determined with an automatic cell counter (Abacus Junior Vet, Diatron), using the pre-formatted software for analyzing horse's blood. The following parameters were included in the hematological analysis: white blood cells (WBC), lymphocytes (LYM), mid cells count (MID), granulocytes (GRA), red blood cells (RBC), hemoglobin (HGB), mean cellular hemoglobin $(\mathrm{MCH})$, mean cellular volume (MCV), platelet cells (PLT), mean platelet volume (MPV), hematocrit (HCT), mean cellular hemoglobin concentration (MCHC) and plateletcrit (PCT). The biochemical profiles were obtained by using a semi-automated biochemistry analyzer (Vet Evolution, BSI) with the appropriate reagent kits, in accordance with the recommended standard protocols. The biochemical panel included the following parameters: aspartate aminotransferase (AST), alkaline phosphatase (AP), urea, creatinine, albumin, total protein, lactate dehydrogenase $(\mathrm{LDH})$, creatine kinase, $\gamma$-glutamyltransferase (GGT), total bilirubin, cholesterol, triglyceride, calcium (Ca) and inorganic phosphorus $(\mathrm{P})$.

\section{Statistical analysis}

The data recorded in this study were presented through mean, median, quartile range and coefficient of variation (CV). Shapiro-Wilk's W test was used in order to assess the normal distribution of the data followed by Levene's test for determination of the homogeneity of variances. Variables with normally distributed data and homogenous variances were compared between groups trough the t-test, otherwise, the MannWhitney U-test was used. Similarity of Balkan donkey with other donkey breeds was examined through the cluster analysis, based on Euclidean distances and Ward's method of linkage. The statistical differences for the five selected morphological parameters among donkey breeds were determined by using t-test. Differences were considered as significant for $\mathrm{P}$ values $<0.05$. Statistical analysis of the results obtained in the experiment was carried out using software STATISTICA v. 6 (StatSoft, Inc., Tulsa, OK, USA).

\section{RESULTS}

The values of body measures displayed homogeneity $(\mathrm{CV}<30 \%)$ in both age categories (Table 1). Most of the body measures for adult donkeys followed normal distribution, while the majority of the variables for young donkeys indicated not-normal data distribution (Shapiro-Wilk's W test, $\mathrm{p}<0.05$ ). Between groups $\mathrm{A}$ and $\mathrm{B}$, there was a significant difference $(\mathrm{p}<0.05)$ in four out of eighteen parameters: body length, head length, chest circumference and body weight. The results of t-test (Table 2) for five selected body measures showed significant differences $(\mathrm{p}<0.01)$ when Balkan donkey (BALK) was compared to the Catalonian donkey (CAT) and Croatian donkeys (LD Littoral-Dinaric donkey; NA - North-Adriatic donkey; IST - Istrian donkey). Comparison of Balkan donkey with Albanian donkey population (ALB) revealed no significant differences in body length values $(p>0.05)$; however, values of chest depth $(p<0.05)$, 
wither height $(\mathrm{p}<0.01)$, chest width $(\mathrm{p}<0.01)$ and chest circumference $(\mathrm{p}<0.01)$ were significantly different (Table 2). Results of hierarchical clustering demonstrated the smallest distance between Balkan donkey and Albanian donkeys (Figure 1).

Table 1. Morphometric measurements for the Balkan donkey breed

\begin{tabular}{|c|c|c|c|c|c|c|c|c|c|}
\hline \multirow[b]{2}{*}{ Body variables $(\mathrm{cm})$} & \multirow[b]{2}{*}{ Mean } & \multicolumn{2}{|c|}{ Age group A } & \multicolumn{6}{|c|}{ Age group B } \\
\hline & & Median & $\begin{array}{c}\text { Quartile } \\
\text { range }\end{array}$ & $\begin{array}{l}\text { CV } \\
(\%)\end{array}$ & Mean & Median & $\begin{array}{c}\text { Quartile } \\
\text { range }\end{array}$ & $\begin{array}{l}\text { CV } \\
(\%)\end{array}$ & $\mathbf{p}$ \\
\hline Wither height & 103.3 & 103.5 & $101.0-107.0$ & 5.7 & 104.9 & 104.0 & $99.0-108.5$ & 8.5 & 0.906 \\
\hline Back height & 101.9 & 101.7 & $99.0-106.0$ & 5.9 & 102.8 & 102.5 & $97.5-106.7$ & 8.4 & 0.873 \\
\hline Chest depth & 47.1 & 46.5 & $45.0-51.0$ & 10.4 & 47.3 & 46.5 & $44.0-50.7$ & 9.9 & 0.859 \\
\hline Hip height & 106.8 & 107.0 & $105.0-111.0$ & 5.0 & 107.2 & 106.71 & $102.0-112.0$ & 7.9 & 0.731 \\
\hline Tarsal height & 40.7 & 40.5 & $39.0-42.0$ & 5.8 & 41.3 & 41.0 & $38.0-44.0$ & 9.2 & 0.541 \\
\hline Carpal height & 32.0 & 31.5 & $30.0-34.0$ & 6.6 & 32.4 & 33.0 & $30.0-34.5$ & 11.7 & 0.757 \\
\hline Body length & 110.3 & 111.5 & $107.0-116.0$ & 8.7 & 117.2 & 117.01 & $112.0-121.5$ & 8.2 & 0.002 \\
\hline Head length ( $t$ ) & 47.6 & 48.0 & $45.0-51.0$ & 7.7 & 49.6 & 49.7 & $47.0-52.0$ & 7.3 & 0.038 \\
\hline Head width & 21.0 & 21.0 & $20.0-22.0$ & 6.8 & 22.1 & 21.7 & $20.7-23.0$ & 12.4 & 0.145 \\
\hline Ear length $(\mathrm{t})$ & 26.1 & 26.0 & $25.0-27.0$ & 8.2 & 25.6 & 25.0 & $24.0-27.0$ & 8.4 & 0.318 \\
\hline Croup length & 29.4 & 31.5 & $25.0-33.0$ & 17.1 & 29.9 & 32.0 & $24.0-35.0$ & 21.3 & 0.674 \\
\hline Croup width & 33.7 & 34.0 & $33.0-36.0$ & 12.3 & 35.0 & 36.0 & $32.5-38.0$ & 12.5 & 0.198 \\
\hline Chest width & 23.9 & 24.0 & $23.0-25.0$ & 11.0 & 24.3 & 24.2 & $22.5-27.0$ & 11.9 & 0.609 \\
\hline Chest circumference & 114.2 & 114.7 & $112.5-118.0$ & 8.0 & 119.6 & 118.51 & $114.5-124.5$ & 8.8 & 0.030 \\
\hline Carpal circumference & 21.0 & 21.0 & $20.5-22.0$ & 6.8 & 21.4 & 21.0 & $19.7-22.5$ & 11.5 & 0.896 \\
\hline Tarsal circumference & 27.3 & 27.0 & $26.0-29.0$ & 7.7 & 28.6 & 28.0 & $27.0-29.0$ & 10.3 & 0.142 \\
\hline Tibia circumference & 23.9 & 24.0 & $23.0-25.0$ & 10.7 & 25.0 & 25.0 & $23.7-26.2$ & 12.1 & 0.275 \\
\hline Body Weight (kg) & 124.9 & 122.0 & $111.0-132.0$ & 16.9 & 143.4 & 138.512 & $123.5-155.0$ & 24.8 & 0.005 \\
\hline
\end{tabular}

( $t$ ) $-t$ test; for the rest of the variables $U$ test was used

The homogeneity of results was recorded for the majority of investigated hematological parameters. The exceptions were LYM, MID, GRA, PLT and PCT in both age groups, and WBC values in adults (Table 3). The hematological values determined for young donkeys were normally distributed. In group B, the values of WBC, LYM, MID, GRA, PLT and PCT did not follow the normal distribution model. U-test indicated that WBC, MID and GRA counts were significantly higher $(\mathrm{p}<0.05)$ in donkeys under 3 years of age compared to adult animals.

The biochemical parameters showed the highest variability within each group (Table 4.). Five analytes (AST, GGT, cholesterol, $\mathrm{Ca}, \mathrm{P}$ ) of donkeys from group A displayed non-normal distribution. In group B, results of four analytes (albumin, total protein, LDH, GGT) followed normal distribution. There was no apparent age effect on 


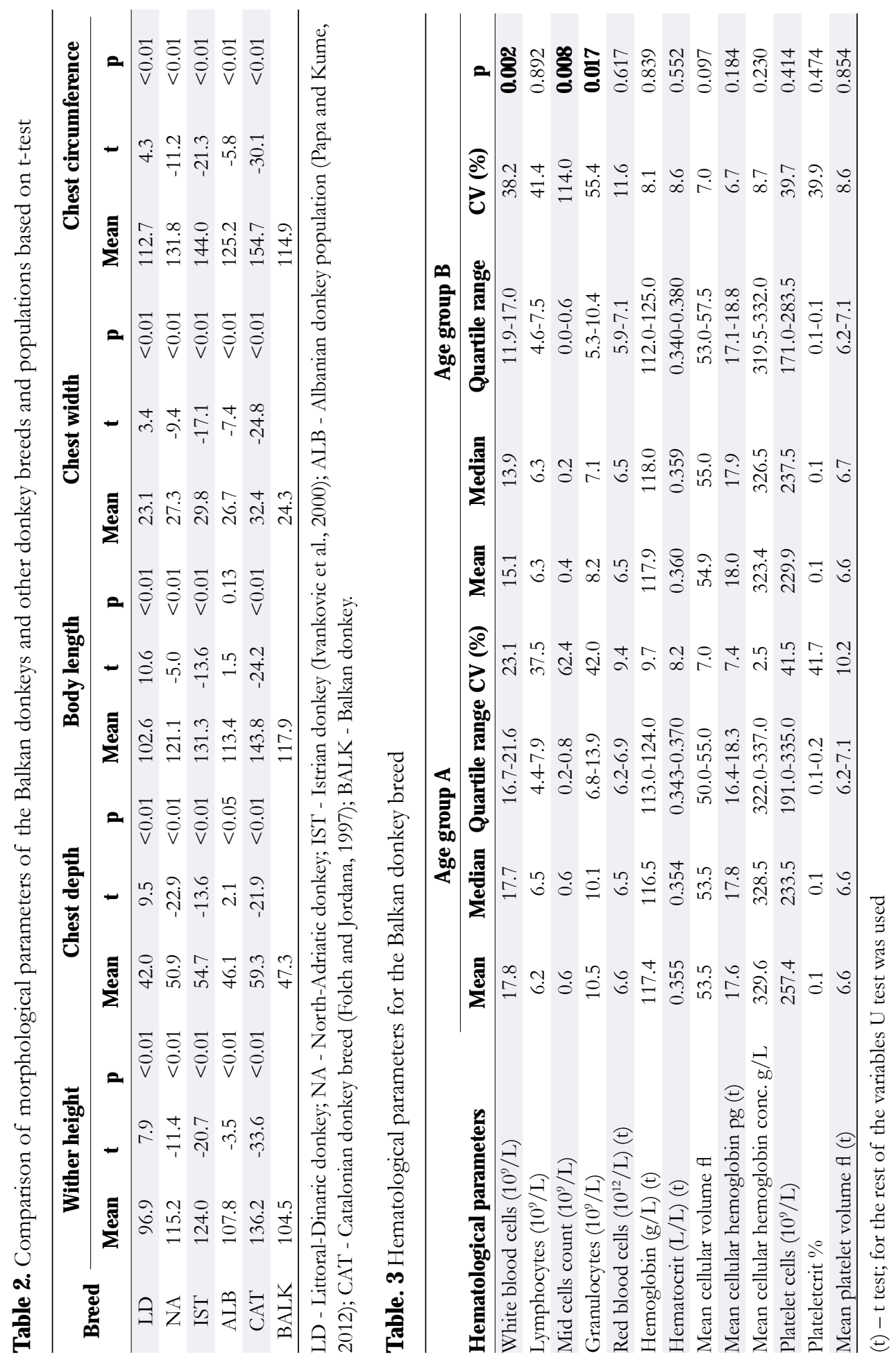




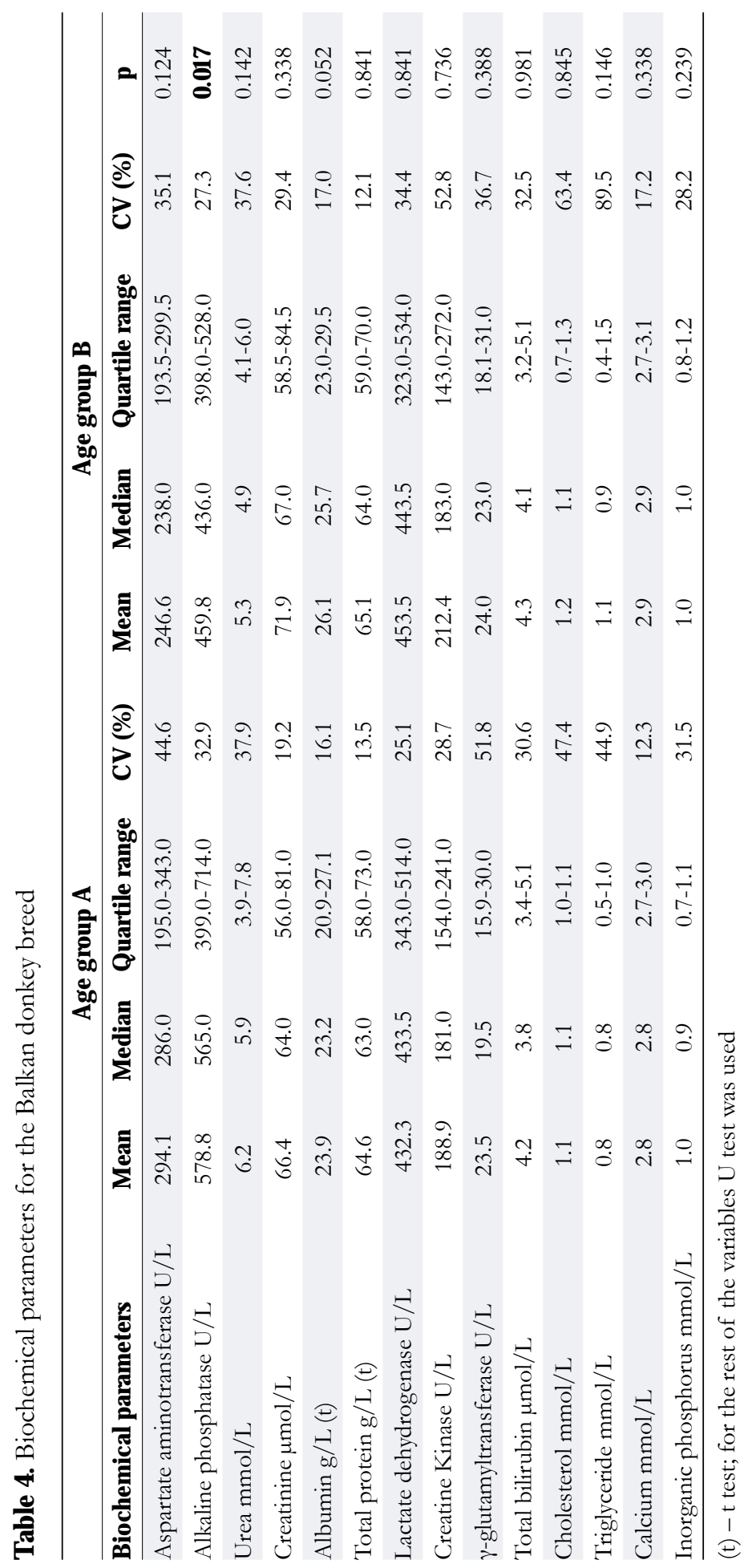


biochemical parameters since no significant difference was noted for any of the parameters between the two age groups. The only exception was alkaline phosphatase. In young donkeys values for alkaline phosphatase were significantly higher $(\mathrm{p}<0.05)$ compared to the values recorded in adult donkeys.

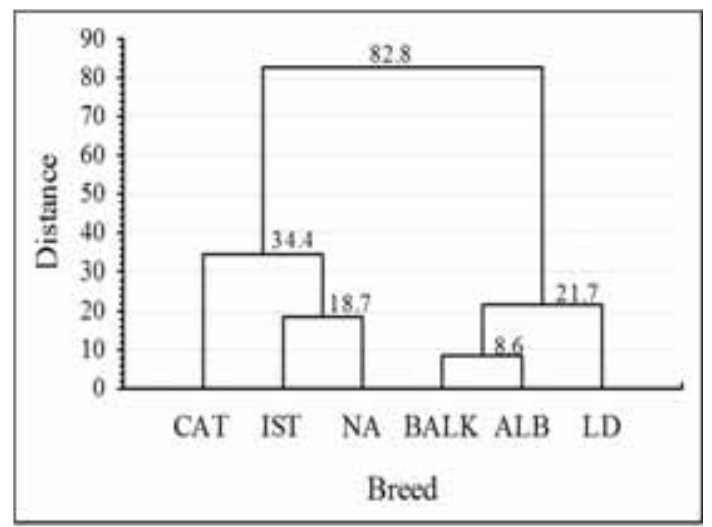

Figure 1. Dendrogram of the cluster analysis showing relationships among the Domestic Balkan donkey and previously described European donkey breeds, based on morphometric data. LD - Littoral-Dinaric donkey; NA - North-Adriatic donkey; IST - Istrian donkey (Ivankovic et al., 2000); ALB - Albanian donkey population (Papa and Kume, 2012); CAT - Catalonian donkey breed (Folch and Jordana, 1997); BALK - Balkan donkey

\section{DISCUSSION}

In this study the Balkan donkey breed was characterized through morfometric, hematological and biochemical investigation. The obtained values were compared between donkeys classified into group A ( $\leq 3$ years of age) and group B ( $>3$ years of age). Body measure values for both groups of animals disclosed high homogeneity $(5.08 \% \leq \mathrm{CV} \leq 24.8 \%)$ although three different geographical populations of donkeys have been investigated. This high level of homogeneity points out to the uniformity of morphometric characteristics of the Balkan donkey breed. Significant morphometric differences in body length, head length, chest circumference and body weight were found between age groups. Since body weight was calculated using body length and chest circumference, changes in these parameters obviously generated the change in weight. Comparison of the selected morphological parameters revealed significant differences among the Balkan donkey and other donkey breeds (Catalonian, Croatian and Albanian). Morphological similarity, as indicated by hierarchical clustering between Balkan donkey and Albanian donkeys, could be attributed to close geographic proximity and the overlap of their habitats. This imposes the need for additional molecular characterization of both breeds to get insight in their molecular genetics diversity. According to the normal distribution of the body measures determined and significant morphological differences in wither height, chest depth, body length, chest width and chest circumference among the all above mentioned breeds, recorded values for Balkan donkey could be taken as referent. 
The hematological values established in this study are consistent with previously published data for donkeys from USA [18], the United Kingdom [19], Catalonian donkey [8] and Ragusana donkey [21]. Three out of 13 hematological variables showed significant differences $(\mathrm{p}<0.05)$ between groups $A$ and $\mathrm{B}$. WBC, MID and GRA counts showed a significant decrease with age, while LYM number did not seem to be influenced. Similar results were reported by Zinkl et al. [18] in the American donkey population. The average values of hematological parameters for Balkan donkey obtained in our study are in disagreement with previous report of Vucicevic et al. [26]. The differences may be due to the small sample size tested in the study by Vucicevic et al. [26] or to discrepancies in the applied methodologies. It has already been shown that differences in hematological profiles could be attributed to various processing techniques and/or applied instruments [21], as well as the geographical and nutritional factors [28].

The overall data of this study indicate that serum biochemical parameters obtained for the Balkan donkey were consistent with previous reports and within the recommended reference range [9,18-23]. The results of biochemical analysis revealed significant differences $(p<0.05)$ between group A and B only for alkaline phosphatase, which is in accordance with findings of Zinkl et al. [18]. The investigation of French and Patrick [19] on a large sample of approximately 4000 donkeys also showed that biochemical parameters were not affected by age. However, according to the other studies [9,2023] more than one biochemical variable significantly differed between populations of young and adult donkeys. There was no significant variation in the mean values of plasmatic phosphorus concentration within the different age groups, although higher values were usually reported in younger donkeys [9, 20]. According to Jordana et al. [9], the inconsistency of published results for some variables could be explained by the inappropriate use of parametric statistic on a small non-normal sample. In addition, factors such as difference in geographical conditions, season or climate, physiological conditions of sampled donkeys, test methodology and equipment used for analyses, could also contributed to the disparity of the results [21].

This paper represents the first comprehensive morphometric, hematological and biochemical characterization of the endangered Balkan donkey breed. The results of morphometric analyses showed consistency of the obtained values within the breed, and differences when compared to other previously described donkey breeds. The information gained through the process of characterization provides a basis for conservation and development of the breed standard. This study is an introduction to a genetic research of donkey populations in Serbia, which is currently underway in our laboratory. The obtained results will provide useful information for farmers, governments and other organizations to make well based judgments in order to preserve donkeys as animal genetic resource [6].

\section{Acknowledgments}

This study was supported by the Ministry of Education, Science and Technological Development of the Republic of Serbia (Grant No III 46002). The authors are also 
grateful to Mr. Slobodan Simic from SNR "Zasavica", Mr. Mile Plavsic from Kovili and Mr. Sergej Ivanov from Stara planina Mt. region and all respective local farmers for their great support to our research.

\section{REFERENCES}

1. Beja-Pereira A, England PR, Ferrand N, Jordan S, Bakhiet AO, Abdalla MA, Mashkour M, Jordana J, Taberlet P, Luikart G: African origins of the domestic donkey. Science 2004, 304:1781-1781.

2. Kugler W, Grunenfelder HP, Broxham E: Donkey breeds in Europe. St. Gallen, Switzerland: Monitoring institute for rare breeds and seeds in Europe; 2008.

3. Savic M, Trailovic R, Petrujkic B, Beckei Z, Dimitrijevic B, Dimitrijevic V: Determining the value of Vlashko-Vitoroga Zackel sheep for the conservation process. Acta Vet-Beograd 2013, 63: 621-629.

4. Grdovic S, Savic M, Beckei Z, Dimitrijevic B: Biodiversity and traditional sheep grazing in the south Banat region. Acta Vet-Beograd 2012, 62: 709-716.

5. Rischkowsky B, Pilling D, (ed.): The state of the world's animal genetic resources for food and agriculture. Rome, Italy: Food and Agriculture Organization; 2007.

6. FAO: Molecular-genetic characterization of animal genetic resources. Rome, Italy: Food and Agriculture Organization; 2011.

7. Folch P, Jordana J: Characterization, reference ranges and the influence of gender on morphological parameters of the endangered Catalonian donkey breed. J Equine Vet Sci 1997, 17:102-111.

8. Folch P, Jordana J, Cuenca R: Reference Ranges and the Influence of Age and Sex on Hematological Values of the Endangered Catalonian Donkey. Vet J 1997, 154: 163-168.

9. Jordana J, Folch P, Cuenca R: Clinical biochemical parameters of the endangered Catalonian donkey breed: normal values and the influence of sex, age, and management practices effect. Res Vet Sci 1998, 64:7-10.

10. Jordana J, Folch P, Sanchez A: Genetic variation (protein markers and microsatellites) in endangered Catalonian donkeys. Biochem Syst Ecol 1999, 27:791-798.

11. Aranguren-Mendez J, Jordana J, Gomez M: Genetic diversity in Spanish donkey breeds using microsatellite DNA markers. Genet Sel Evol 2001, 33:433-442.

12. Aranguren-Mendez J, Beja-Pereira A., Avellanet R, Dzama K, Jordana J. Mitochondrial DNA variation and genetic relationships in Spanish donkey breeds (Equus asinus). J Anim Breed Genet 2004, 121:319-330.

13. Ivankovic A, Caput P, Mioc B, Pavic V: The phenotype Features of Donkeys in Croatia. ACS 2000, 65:99-105.

14. Ivankovic A, Kavar T, Caput P, Mioc B, Pavic V, Dovc P: Genetic diversity of three donkey populations in the Croatian coastal region. Anim Genet 2002, 33:169-177.

15. Official Gazette of Republic of Serbia, No. 38/10.

16. Trailovic R, Ivanov S, Dimitrijevic V, Trailovic D: Some morphological and health characteristics of domestic Balkan donkey in Stara planina. In Proceedings of $2^{\text {nd }}$ International Fair of Horse Breeding, 30 September - 2 October 2011, Novi Sad, Serbia, pp. 180-187. 
17. Papa L, Kume K: The results of identification and characterisation of the donkey population in Albania. Agr Forest 2012, 58:125-134.

18. Zinkl JG, Mae D, Merida GP, Farver TB, Humble JA: Reference ranges and the influence of age and sex on hematologic and serum biochemical values in donkeys (E quus asinus). Am J Vet Res 1990, 51:408-41.

19. French JM, Patrick VH: Reference values for physiological, hematological and biochemical parameters in domestic donkeys (E quus asinus). Equine Vet Educ 1995, 7:33-35.

20. Mori E, Fernandes WR, Mirandola RMS, Kubo G, Ferreira RR, Oliveira JV, Gacek F: Reference values on serum biochemical parameters of Brazilian donkey (E quus asinus) breed. J Equine Vet Sci 2003, 23:358-364.

21. Caldin M, Furlanello T, Solano-Gallego L, De Lorenzi D, Carli E, Tasca S, Lubas G: Reference ranges for hematology, biochemical profile and electrophoresis in a single herd of Ragusana donkeys from Sicily (Italy). Comp Clin Pathol 2005, 14:5-12.

22. Sow A, Kalandi KM, Ndiaye NP, Bathily A, Sawadogo GJ: Clinical biochemical parameters of Burkinabese local donkeys' breeds. Inter Res J Biochem Bioinformatics 2012, 2:84-89.

23. Girardi AM, Marques LC, de Toledo CZP, Barbosa JC, Maldonado JrW, Jorge RLN, da Silva Nogueira CA: Biochemical profile of the Pega donkey (E quus asinus) breed: influence of age and sex. Comp Clin Pathol 2013, DOI:10.1007/S0058001317184.

24. Dugat SL, Taylor TS, Matthews NS, Gold JR: Values for triglycerides, insulin, cortisol, and ACTH in a herd of normal donkeys. J Equine Vet Sci 2010, 30:141-144.

25. Alberghina D, Fazio F, Arfuso F, Sciano S, Zumbo A, Piccione G: Reference intervals of serum protein concentrations from clinically healthy female Ragusana donkeys (E quus asinus) determined by cellulose acetate electrophoresis. J Equine Vet Sci 2012, 33:433-436.

26. Vucicevic M, Drljacic A, Francuski J, Ivanov S, Trailovic R, Trailovic D: Estimation of physiological values of haematological parameters in Domestic Balkan donkey before and after the grazing period. In Proceedings of $2^{\text {nd }}$ International Fair of Horse Breeding, 30 September - 2 October 2011, Novi Sad, Serbia, pp. 194-200.

27. Pejić N: Konj (E quus caballus). Novi Sad, Serbia: Faculty of Agriculture Novi Sad, 1996.

28. Fowler ME, Zinkl JG: Reference ranges for hematologic and serum biochemical values in llamas (L ama glama). Am J Vet Res 1989, 50:2049-2053.

\section{MORFOMETRIJSKA, BIOHEMIJSKA I HEMATOLOŠKA KARAKTERIZACIJA UGROŽENE RASE BALKANSKI MAGARAC}

STANIŠIĆ Ljubodrag, DIMITRIJEVIĆ Vladimir, SIMEUNOVIĆ Predrag, LAKIĆ Nada, RADOVIĆ Ivica, IVANKOVIĆ Ante, STEVANOVIĆ Jevrosima, STANIMIROVIĆ Zoran

Cilj ovog rada bio je utvdivanje morfometrijskih, biohemijskih i hematoloških vrednosti rase balkanski magarac iz Srbije, kao i ispitivanje uticaja starosti na testirane parametre. Dobijeni morfometrijski podaci za balkanskog magarca upoređeni su sa dostupnim morfometrijskim vrednostima prethodno okarakterisanih rasa magaraca $u$ cilju utvrđivanja sličnosti. Istraživanjem je obuhvaćeno 74 magarca, podeljenih u dve starosne grupe (grupa A $\leq 3$ godine; grupa B $>3$ godine). Analizirano je 18 morfo- 
metrijskih, 13 hematoloških i 14 biohemijskih parametara. Između dve starosne grupe utvrđene su značajne morfometrijske razlike $(\mathrm{p}<0.05)$ u dužini tela i glave, obimu grudi i telesnoj težini. Između balkanskog magarca i drugih ispitivanih rasa (katalonski, hrvatski i albanski) utvrđene su značajne razlike u morfološkim parametrima. Klaster analiza telesnih mera ukazala je na najmanju udaljenost između balkanskog magarca i albanskih magaraca. Rezultati morfometrijskih analiza balkanskog magarca ukazali su na konzistentnost dobijenih vrednosti u okviru ove rase i razlike u odnosu na druge rase magaraca. Stoga se dobijene vrednosti mogu uzeti kao referentne za balkanskog magarca. Hematološki i biohemijski profili dobijeni za balkanskog magarca su u skladu sa ranijim izveštajima i unutar preporučenih referentnih vrednosti. Broj granulocita, belih krvnih i MID ćelija su pokazali značajno veće $(\mathrm{p}<0.05)$ vrednosti kod magaraca ispod 3 godine starosti, dok je alkalna fosfataza jedini biohemijski parametar pod uticajem starosti. Sprovedena morfometrijska, hematološka i biohemijska karakterizacija balkanskog magarca pruža osnov za očuvanje i razvoj standarda ove rase. 